\title{
Strategi Pembelajaran dalam Mengatasi Kesulitan Belajar Online Anak Usia Dini
}

\author{
Khairunnisa Ulfadhilah ${ }^{1}$ \\ ${ }^{1}$ Univesitas Islam Negeri Sunan Kalijaga Yogyakarta-Indonesia \\ Email: khairunnisaulfadhilah51045@gmail.com
}

\begin{tabular}{llll}
\hline Submitted & : January $22^{\text {nd }}, 2021$ & Revision & : June $4^{\text {th }}, 2021$ \\
Reviewed & $:$ April $7^{\text {th }}, 2021$ & Published & $:$ June $7^{\text {th }}, 2021$ \\
\hline
\end{tabular}

\begin{abstract}
COVID-19 has an impact on all levels of education in Indonesia and has a major impact on early childhood, where the teaching and learning process needs to be done face-to-face, but due to the COVID-19 outbreak, the government's policy of face-to-face learning and online learning is carried out. Researchers conducting this research are interested in the learning strategies used by educators during the COVID-19 pandemic so that they can become a reference for parents in guiding children to learn online. The effect of learning for early childhood is difficulty in understanding explanations from educators, lack of socialization in children's lives because schools are held online, children's development and growth has decreased, children's achievement indicators will decrease. Online learning for children aged during this pandemic is not optimal because it has obstacles, namely COVID-19, which is the reason children experience the impact of learning at home. The research method used qualitative research to describe the findings in the field and then processed the data. The data collection techniques in the research that have been carried out are observation, interviews, and documentation. The results of this research are so that parents can guide, supervise and become a place for children's education in the family. Parents have a very big responsibility in educating and guiding children's learning online, the success of children's learning will be determined by parents if parents provide stimulation or guide when learning online.
\end{abstract}

Keywords: COVID-19, Online Learning, Parents.

COVID-19 berdampak semua jenjang pendidikan di Indonesia dan berdampak besar pada jenjang anak usia dini, dimana pada proses belajar-mengajar perlu dilakukan secara tatap muka namun adanya wabah COVID-19 ini maka kebijakan pemerintah belajar tatap muka dan dilakukan pembelajaran daring atau online. Peneliti melakukan 
penelitian ini tertarik dengan strategi pembelajaran yang digunakan oleh pendidik selama pandemi COVID-19 sehingga mampu menjadi referensi orang tua dalam membimbing anak belajar secara online. Pengaruh pembelajaran bagi anak usia dini kesulitan dalam memahami penjelasan dari pendidik, kurang nya sosialisasi dalam kehidupan anak sebab sekolah diadakan online, perkembangan dan perumbuhan anak mengalami penurunan, indkator pencapaian anak akan mengalami penurunan. Pembelajaran online bagi anak usia dimasa pandemi ini kurang optimal dikarenakan mempunyai kendala yakni COVID-19 ini menjadi alasan anak mengalami dampak pembelajaran dirumah. Metode penelitian menggunakan penelitian kualitatif untuk mendeskripsikan temuan dilapangan kemudian diolah data. Teknik pengumpulan data pada riset telah dilaksanakan merupakan observasi, wawancara, dan dokumentasi. Hasil dari riset ini agar orang tua dapat membimbing, mengawasi dan menjadi wadah pendidikan anak dalam keluarga. Orang tua memiliki tanggung jawab sangat besar dalam mendidik maupun membimbing belajar anak secara online, keberhasilan belajar anak akan ditentukan oleh orang tua jika orang tua memberikan stimulasi ataupun membimbing saat belajar secara online.

Kata Kunci: COVID-19, Pembelajaran Online, Orang tua.

\section{Pendahuluan}

Wabah Coronavirus 2019 atau yang disebut COVID-19 ialah penyakit baru yang misterius Wuhan, Cina (Masa et al., 2021). Wabah COVID-19 masih mengintai masyarakat di dunia bahkan di Indonesia, Indonesia salah satu negara tertinggi terkena wabah COVID-19 (Ra \& Bima, 2021). Efek dari wabah ini berdampak pada semua bidang di Indonesia termasuk bidang pendidikan mengalami efek besar dalam hal ini (Oktaria \& Putra, 2020). Dalam memutus rantai penyebaran pemerintah melalui kementerian pendidikan dan kebudayan indonesia menetapkan bahwa belajar-mengajar semua jenjang pendidikan melakukan belajar dirumah atau dkenala sbagai belajar online ataupun daring (Kemendikbud, 2020).

Mendikbud nomor 4 tahun 2020 mengenai pedman surat ederan menjelaskan tujuan anak Proses Belajar Dari Rumah (BDR) agar melndung, memutuskan ranta penyebaran virus COVID-19 sebab penyebaran nya sangat cepat, pendidik diberikan dukungan dalam psikososial, anak didik dan orang tua. Selain itu, 23 laman konten agar orang tua dan pendidik dapat belajar dirumah selama pandemi sebagai sumber belajar (Kemendikbud, 2020).

Menurut (Angka, 2021) semua jenjang pendidikan di Indonesia mengalami proses belajar-mengajar dirumah selama pandemi ini, tak hanya belajar-mengajar 
dilakukan dirumah bekerja, ibadah dan kegiatan lainnya dilakukan dirumah. Hal ini sesuatu yang harus dilakukan masyarakat walaupun akan terasa asing, jenuh namun ini cara-cara jitu agar memutus rantai penyebaran serta hal yang baru bagi dunia pendidikan, pengajaran di sektor semua jenjang pendidikan (Belajar \& Siswa, 2020).

Kini kehidupan di Indonesia mengalami perubahan yang dapat dikenal dengan new normal yang mana semua kegiatan baik proses mengajar, bekerja, beribadah serta kegiatan lainnya dilakukan seperti biasa namun yang membedakan dilakukan jadi semua masyarakat yang melakukan kegiatan diluar perlu menerapkan tersebut, dan menjauhi kerumunan agar menangulangi wabah ini (Wakhidah \& Umah, 2020). Dalam pemberlakuan aturan baru, hal yang asing dan tantangan besar bagi masyarakat maka dari iu perlu pembiasaan dalam hal ini.

Mengetahui proses pembelajaran anak dengan baik ketika dirumah serta efektif dalam pembelajaran (PAUD Lectura: Jurnal Pendidikan Anak Usia Dini, Vol 4, No 1, Oktober 2020, 2020). Saling bekerja sama satu sama lain yakni pendidik dan orang tua masa pandemi ini agar dapat berkomunikasi dengan baik, dapat memantau pertumbuhan dan perkembangan anak (Wakhidah \& Umah, 2020). Selain dilaukan pembelajaran online, pihak sekolah perlu mengadakan parenting online bagi orang tua agar memudahkan didikan yang terbaik, mengawasi anak dalam hal pebelajaran online dirumah. Sebab selama ada COVID-19 ini orang tua menjadi pendidik berperan untuk menjelaskan, mengawasi dan mendidik anak ketika anak mengalami kesulitan.

Membimbing yang dilakukan dirumah yang dianjurkan oleh pemerintah dan pihak sekolah mengikuti aturan tersebut (Oktaria \& Putra, 2020), orang tua perlu membagi waktu untuk melakukan pekerjaan lainnya dan membimbing anak ketika melakukan pembelajaran daring melalui aplikasi whatsapp, zoom meeting, google meet ataupun website lembaga sekolah anak.

Orang tua sebagai "coach" bagi anak ketika dirumah untuk membantu dka dirumah serta memfasilitasi proses belajar anak sebab dalam proses tersebut anak akan mengalami kesulitan dengan adanya COVID-19, orang tua yang menjadi pendidik dalam pembelajaran (Anugrahana, 2020). Masalah anak dalam menghadapi proses pembelajaran saat pandemi ini, tidak mengerti akan penjelasan dari pendidik ataupun tugas dari pendidik, anak telat mengumpulkan tugas sebab anak mengalami kesulitan membimbing, mengawasi, menstimulasi dan memberikan rewards and punishment dengan baik dan paling utama ketika orang 
tua sebagai "coach" bagi anak saat COVID-19 masih melanda di Indonesia (Covid\& Suhendro, 2020) Orang tua dan pendidik mengapa perlu berkomunikasi dengan baik untuk mengetahui pertumbuhan maupun perkembangan saat pembelajaran online dirumah selain itu, perlu memperhatikan psikologis anak dikarenakan agar menyesuaikan cara membimbing anak sebab pendidik mengetahui cara belajar anak seperti apa sebab setiap anak akan berbeda cara belajar anak (Inten et al., 2019). Orang tua perlu memberikan suasana belajar yang menyenangkan agar tidak membuat anak Badmood dalam belajar, orang tua pun perlu menghindari memaksaan anak akan berdampak negatif pada perkembangan anak sebab orang tua dan pendidik berkontribusi dalam memaksimalkan belajar anak pada masa COVID-19 ini (Anhusadar, 2021).

Orang tua perlu mengerti akan teknologi sebab merupakan hal utama untuk memfasilitasi pembelajaran anak berbasin online pada pandemi ini, merupakan hal dan tantangan baru bagi orang tua agar berjalan pembelajaran sesuai kurikulum yang sudah ada, dan ketika melakukan pembelajaran dirumah (Kusuma \& Sutapa, 2021). Para pendidik dituntut untuk profesional agar dapat memberikan motivasi, semangat belajar anak yang menjadi tantangan pendidik kali ini adalah masa pandemi COVID-19, anak-anak belajar dilakukan rumah masing-masing secara online atau online (Covid- \& Suhendro, 2020). Pembelajaran online merupakan akronim dari sistem pembelajaran online yang dilakukan jarak jauh, dalam hal ini pendidik dan anak tidak bertatap muka untuk memutus rantai penyebaran COVID-19 (Kusuma \& Sutapa, 2021).

Mediawati mepaparkan jika pembelajaran online adalah suatu bentuk pada masa pandemi ini, pendidikan formal yang dilaksanakan oleh sekolah terjadi ketika pendidik dan ank-anak tidak berada ditempat yang sama, melainkan ditempat yang terpisah. Pembelajaran online dapat dilakukan kapanpun dan dimanapun (Fitri, 2020). Menurut peneliti, pembelajaran online merupakan metode pembelajran dengan bidang yang lebih terbuka, menggunakan akses dan teknologi jaringan internet untuk mendukung suatu proses pembelajran yang dapat diselesaikan kapanpun, dimanapun tana harus bersinggungan dengan aktu, tanpa harus tatap muka atau waktu.

Dalam pembelajaran jarak jauh, ada dua cara komunikasi. Pertama, sinskronisasi adalah interaksi antara pendidk, dan anak secara bersamaan (online tatap muka) dalam jangka waktu tertentu (Matematika et al., 2021). Contoh teknologi komunikasi yang dapat digunakan antara lain zoom, google meet. Kedua, 
asynchronous yaitu interaksi anatar pendidik dengan anak tidak melakukan secara langsung hanya dapat menggunakan via aplikasi. Interaksi dapt dilakukan pada waktu yang berbeda, sesuai dengan kondisi relatif atau kecepatan belajar masingmasing sehingga ank dapat mengakses materi dengan pendidik setiap saat.

Pembelajaran online merupakan sistem pembelajaran yang harus dipelajri dengan seksama dan mendalam, jangan abaikan pendidikan online ini sebab aspek objektif dari pembelajaran anak (Satrianingrum et al., 2021). Hal ini akan sangat mempengaruhi potensi perkembangan anak usia dini, jika anak akan kehilangan pondasi awal dan persiapan untuk pendidikan selanjutnya. Proses pendidikan onlne ini mengubah pendikan tatap muka ke dalam bentuk digtal yang tentunya memiliki peluang dan tantangan yang sangat sulit. Oleh kaena itu, adamasalah dalam prosesnya pembelajaran pada anak dan harus dapat dicarikan solusinya.

Penerapan berbagai strategi pembelajaran merupakan solusi untuk menemukan bahan yang tepat dala mentransformasikan pengetahuan anak mejadi kondusif bagi perkembangan aspek anak (Covid-, 2021). Tentunya peran pendidik harus mampu bekeja sam dengan semua pihak, terlebh lagi pada saat wabah ini masih trus terjadi, sebagai jembatan antara orang tua dan sekolah dalam melaksankan strategi pembelajaran (Aji et al., 2020). Pengunaan strategi pembelajaran yang relevan akan sangat mempengarhi kecerdasaan setiap anak. Studi ini menyelidiki berbagai strategi pembelajaran yang digunakan oleh pendidik selama pandemi COVID-19 sehingga dapat dijadikan referensi dalam pembelajaran anak usia dni sat pandemi ini dengan cara membimbing anak saat belajar online, membantu anak saat belajar online jika anak menemukan kendala ataupun masalah seperti kesalahan teknis. Pembelajaran online rentan sekali terjadinya kendala ataupun kesalahan teknis seperti signal yang kurang stabil, kuota internet yang sedikit maka akan berpengaruh pada jalannya belajar online akan menjadi tidak efektif. Maka dari itu pendidik mengupayakan kepada orang tua untuk mencari solusi dengan cara sekolah memberikan kuota gratis untuk anak didik dalam melakukan pembelajaran online dilakukan, dan orang tua mampu menjadi pendidik untuk anak saat belajar online berlangsung.

Penelitian ini menggunakan pendekatan kualitatif, penelitian ini dilakukan di TKIT Al-Umm Cirebon. Teknik pengumupulan data dalam penelitian ini menggunakan teknik wawancara, observasi, dan dokumentasi. Peneliti mengumpulkan data dengan melakukan observasi langsung disekolah TKIT AlUmm Cirebon, melakukan wawancara dengan kepala sekolah maupun pendidik. Selain itu, menggunakan dokumentasi untuk menambah informasi dalam penelitian 
guna memperoleh data yang dibutuhkan oleh peneliti. Teknik keabsahan data yang digunakan dalam penelitian ini menggunakan teknik triangulasi guna menggali, dan membandingkan hasil wawancara terhadap objek penelitian.

\section{Pendidikan Anak Usia Dini}

Pendidikan anak usia dini yakni lembaga, perlu anak lakukan guna agar diasah kemampuan, bakat, membimbing dan menstimulasi perkembangan anak (Ulfah, 2020). Anak usia dini berusia 0-6 tahun waktu yang tepat dimana pendidik dan orang tua melakukan rangsangan terhadap semua perkembangan anak melalui pembelajaran sehingga dapat mencetak generasi bangsa yang unggul.

Anak berusia 0-6 tahun ialah periode dini yang berarti, dan sejauh dalam perkembangan dan pertumbuhan anak. Ketika anak berusia dini seluruh kemampuan tumbuh sangat cepat, dan kilat. Seorang pakar neuorologi, memaparkan jika sekitar 50\% kemampuan bernalar sanggup terjalin pada berusia 4 tahun serta $80 \%$ sudah terjadi kala berumur 8 tahun (Khadijah, 2016). Fase kanak-kanak akan menjajaki masa keemasan (the golden), dimana pada tahapan ini merasakan ataupun mengetahui bermacam dorongan maupun stimulasi yang diberikan oleh orang tua, dan pendidik. Tahapan peka merupakan momen terbentuknya area fungsi tubuh, serta mental yang siap untuk anak. Fase kini pula ialah pondasi dasar untuk meningkatkan kemampuan kognitif, fisik motorik, bahasa, sosio- emosional, agama, dan moral, dan seni. Menggiatkan untuk anak lewat sekolah RA dan sederajatnya dapat menghasilkan sel-sel saraf anak maksimal, agar bermanfaat untuk pertumbuhan kecerdasan otak anak. Sel-sel saraf otak akan mengotomatiskan kemudian mengacu pada pertumbuhan semacam nilai agama dan moral, kognitif, sosio- emosinal, kreativitas, bahasa dan seni. Kemampuan maupun peran seni dalam diri anak usia dini tidak dapat dilupanja begitu saja, sebab seni sudah menjadi bagian dari kehidupan anak- anak tidak hanya itu dunia anak- anak bermain. Dengan bermain dapat dicampurkan dengan seni agar anak lebih memahami tentang seni.

Manfaat dari PAUD meningkatkan karakter, dan kemampuan secara optimal, membagikan stimulasi ataupun rangsangan dan berpotensi agar anak dapat meningkatkan masa the golden age. Di selengarakan PAUD bertujuan untuk kesiapan anak memasuki pendidikan lebih lanjut, menolong sejak awal agar kelalaian tidak terjadi disebabkan awam akan penting pendidikan, tingkatkan 
kualitas pembelajaran, kurangi laju putus sekolah (Suyadi \& Maulidya Ulfah, 2015). Akan memahami dan menguasai akan perkembangan anak dari bermacam aspek nilai agama dan moral, fisik motorik, kognitif, sosial emosional, bahasa dan seni. Akan mengenali sosial yang tepat yang hendak diterapkan dalam kehidupan anakanak, dan memperoleh panduan Islam dalam menanamkan pembelajaran kepada anak dengan metode yang sangat efisien, aplikatif, pas dan target dengan sederhana.

Anak yang berusia 0-6 tahun dinamakan usia dini, dan mempunyai kepribadian unik, memiliki fase perkembangan dan pertumbuhan dalam diri anak berumur 0-6 tahun terdapat aspek perkembangan digunakan tepat, proses dipijak. Terdapat sebagian definisi mengutarakan pendapatnya, peneliti merumuskan bahwasanya anak yang berusia 0-6 tahun merupakan anak yang berumur 0- 6 tahun dalam tahap perkembangan serta pertumbuhan sesuai pencapaian indikator (Anggraini, 2019).

Ketika anak usia dini kerap diucap sebutan“ golden age” ataupun masa keemasan. Dalam hal ini nyaris segala kemampuan anak mengenai kepekaan anak timbul untuk berkembang serta tumbuh secara signifkan dan hebat. Pertumbuhan tiap anak tidak sama sebab tiap anak mempunyai pertumbuhan yang berbeda, santapan dan konsumsi anak berbeda, dan rangsangan dari orang tua yang inensif sangat diperlukan untuk perkembangan dan pertumbuhan anak agar mempnyai kemajuan. Sebagaimana mestinya anak perlu diberikan stimulasi maupun rangsagan secara intensif, dan berkala dari orang tua ketika dirumah, pendidi ketika disekolah, dan lingkungan yang mendukung akan proses aspek perkembangan anak . Saat anak- anak memasuki tahapan kemudian meningkatkan kemampuan yang terdapat dalam dirinya, mereka akan berekspesi menyenangkan ketika melakukan kegiatan yang ia sukai seperti halnya bermain dirumah maupun diluar bersama teman sebayanya, selain bermain meningkatkan kognitif, bahasa anak pun terlatih dengan adanya berinteraksi, dan berkmuniksi dengan teman sebaya. Sedemikian diperlukan usaha dalam hal pembelajaran untuk menggapai menyeluruh secara optimal dalam perkembangan anak usia dini mengenai pertumbuhan fisik ataupun pertumbuhan psikis. Kemampuan anak sangat berarti, dan penting untuk dikembangkan, stimulasi secara tepat sesuai usia anak.

\section{Dampak COVID-19 Pada Pembelajaran Anak Usia Dini}

Wabah COVID-19 di Indonesia berdampak sangat besar pada semua sektor dari ekonomi hingga pendidikan, angka penyebaran COVID-19 selalu meningkat 
setiap harinya (Covid-, 2021). Maka pemerintah melalui kementerian pendidikan dan kebudayan mengambil langkah serius pada pembelajaran disemua jenjang pendidikan dari TK hingga Peguruan Tinggi untuk melakukan pembelajaran jarak jauh atau yang dikenal sebagai pembelajaran daring. Dampak COVID-19 dirasakan oleh berbagai jenjang pendidikan Indonesia tanpa terkecuali anak usia dini memiliki dampak COVID-19 yang dihadapi proses belajar dirumah sebagai berikut:

\section{Masalah anak dan orang tua}

Peraturan baru yang ditetapkan oleh pemerintah untuk anak belajar dirumah menyebabkan orang tua perlu menyesuaikan untuk memberikan pengarahan pada anak, pembelajaran online bagi orang tua tidaklah mudah untuk membimbing anak sebab anak mengalami penuruna semangat dan kemampuan orang tua dalam membimbing anak menjadi tantangan baru untuk menerapkan pembelajaran (Anugrahana, 2020). Banyak orang tua yang tidak dapat menggunakan smart pintar atau handphone canggih yang mempunyai aplikasi pembelajaran yang baru dalam masa pandemi ini dan anak hanya mendapatkan pembelajaran dari pendidik dalam pembelajaran online. Orang tua sering tidak sabar serta tidak telaten menyebabkan anak dibentak, dimarahi oleh orang tua sehingga tidak baik untuk anak.

Situasi dan kondisi yang tidak kondusif menyebakan anak jenuh dirumah sebab tidak bertemu pendidik, pendidik disekolah berbeda dengan keadaan sebelum adanya virus COVID-19 (Mufaziah \& Fauziah, 2021). Anak mengalami penurunan semangat ketika melakukan pembelajaran online dirumah, orang tua kurang memberikan semangat pada anak sehingga anak tidak nyaman belajar bersama orang tua ketika dirumah beda halnya ketika anak belajar disekolah pendidik memberikan semangat penuh pada anak serta anak leluasa bertemu dan bermain bersama teman-teman disekolah. Pembelajaran dirumah monoton bagi anak sebab orang tua tidak memberikan suasana belajar yang menyenangkan bagi anak, metode yang digunakan itu-itu saja menyebabkan suasana belajar tidak kondusif, cara menjelaskan orang tua dengan pendidik disekolah berbeda jauh. Pengajaran pendidik ketika disekolah menggunakan metode yang menyenangkan bagi anak seperti bermain, bernyanyi, bercerita, dan menggunakan kreativitas lainnya.

Perubahan pembelajaran masa pandemi ini mengakibatkan anak-anak merasakan pembelajaran dirumah kurang menarik, dan membosankan bagi anak. Ruang lingkup anak sedikit mengalami perubahan selain belajar-mengajar menggunakan daring, dan lingkungan pun mengalami perubahan sebab anak-anak dan masyarakat dihimbau agar tetap dirumah saja untuk memutuskan mata rantai 
penyebaran wabah ini. Anak-anak ketika belajar disekolah penuh kreativitas kini adanya wabah ini pembelajaran dilakukan dirumah, orang tua perlu menciptakan suasana pembelajaran menyenangkan bagi anak agar aspek perkembangan anak tidak tersendar adanya pandemi ini. Emosi anak usia dini belumlah stabil, tak dapat mengontrol dirinya maka komunikasi anak sulit untuk menyampaikan apa yang ia rasakan dengan anak rasakan dalam pembelajaran daring.

Masalah selanjutnya ketika dilakukan pembelajaran daring ialah jika orang tua bekerja akan menyulitkan bagi anak melakukan pembelajaran dirumah tanpa ada bimbingan. Berbeda jika membimbing oleh orang tua dengan asisten rumah tangga sebab tidak dapt membimbing daring yang baik, serta orang tua kehilangan momen yang berharga membimbing anak ketika belajar serta tidak mengetahui tumbuh kembang anak secara signifikan. Orang tua yang sama bekerja mempunyai prinsip anak disekolah sedari dini yaitu untuk menitipkan anak ketika orang tua sedang bekerja sehingga anak dapat dibimbing oleh yang profesional disekolah.

Peran orang tua perlu mebimbing anak proses belajar keluarga, orang tua dapat membimbing anaknya beajar dengan anak-ank atau berparisipasi dalam pembelajaran bahkan secara langsung. Bisa mendidik anak, peran seorang pendidik yang biasanya menajar disekolah. Orang tua bisa melapor belajar anak ke pendidk untuk mengetahui pengembangan anak, hambatan anak yang diinstruksikan dan di komunikasikan dalam proses belajar mencari solusi. Menghadapi pandemi COVID-19 juga membutuhkan orang tua memahami perjanjian kesehatan sesuai dengan seruan pemerintah. Ini harus dikomunikasikan kepada anak untuk melatih diri anak untuk menjaga diri sendiri dalam kesehatan secara maksimal sebab anak itu rentan terhadap infeksi di masa kanak-kanak.

\section{Dampak Negatif dalam Pembelajaran Daring}

Hal yang baru bagi anak dan orang tua dalam pembelajaran daring yang mengharuskan anak berkecimpung belajar menggunakan jaringan internet maka terdapat iklan yang mengandung unsur makanan tidak sehat atau konten yang tidak tepat untuk anak usia dini (Mufaziah \& Fauziah, 2021). Anak terus menatap layar ponsel menyebakan mata anak perih, berair sebab terkena radiasi dari ponsel tersebut serta kurangnya sosialisasi anak dimasa pandemi ini. Hal-hal yang tidak tepat untuk anak yang ditonton akan menyebabkan masalah baru pada anak, peran orang tua sangatlah penting serta utama untuk mengawasi anak memakai gawai ataupun pembelajaran daring. 
Dampak selanjutnya yakni ekonomi oang tua pada semua anak berbeda, ada orang tua yang kesulitan dalam membeli kuota internet yang artinya kebutuhan orang tua meningkat dan bertambah selama pandemi ini dan tak jarang banyak orang tua yang kena PHK atas wabah ini. Sosialisasi anak menurun,anak terpaku dengan gawai efek dari itu mata anak mengalami berair, perih, dan merah (Kusuma \& Sutapa, 2021). Untuk menanggulangi hal tersebut orang tua memberikan makanan sehat, membatasi anak untuk belajar online menggunakan gawai dan mengawasi anak dalam menggunakan gawai dalam pembelajaran online. Jaringan inernet yang sulit ditemukan ketika berada di wilayah-wilayah terpencil akan menyulitkan bagi anak melakukan pembelajaran online, dan memperlambat pengiriman tugas pada pendidik atau melakukan pembelajaran tatap muka menggunakan video call akan tersendat. Sebab di bebrapa wilyah terpenci memang sulit mencari signal yang memadai untuk memakai jaringan internet. Ank menghabiskan waktunya dirumah tanpa berbaur dengan lingkungan sekitar, optimalisasi perkembangan anak menurun ketika pembelajaran daring dilakukan.

\section{Problematika bagi Pendidik}

Pembelajaran daring dapt dikatakan hal yang baru, asing dan baru diterapkan pada pembelajaran anak di Indonesia sebab adanya pandemi ini serta penerapan ke anak menemukan kesulitan (Covid- \& Suhendro, 2020). Maka dari itu pendidik perlu menyesuaikan metode belajar-menajar yang baru di era pandemi ini, pendidik, kepala sekolah dan yayasan lembaga sekolah pelu menyesuaikan kurikulum sesuai konidisi pandemi, dan penerapan belajar-mengajar anak secara daring.

Mengenai biaya "kuota" internet yang harus dipublikasikan dengan biaya pendidk sendiri atau oleh yayasan pengajaran. Jika biaya-biaya tersebut dibayarkan kepada pendidk tentunya akan menjadi bean yang berat bagi prsonel yang terlibat. Dibandingkan dengan pembelajran tatap muka disekolah, proses pembelajaran melalui aplikasi belajar online. Pendidk juga bisalangsung memantau aktivtas anakanak melalui orang tua, pembelajaran online terkadang dibatasi oleh masalah signal. Masalah signal ini terkadang tidak stabil sehngga mengangu proses pembelajaran, jikamasalah tersebut sering diemukan akan menimbulkan gangguan. Oleh karena itu, dalam mengadapi metode pembelajran baru di erapandemi diperlukan kesabaran dan ketelitian dari semua pihak terutama pendidik agar dapat menemukan solusi dan inovasi baru untuk mencapai proses pengajaran yang baik. 


\section{Pembelajaran Pada Masa Pandemi}

Pemerintah mendesak rakyatnya untuk penerapan sistem homescholing diperkiran akan rusak rantai penyebaran COVID-19 telah menjadi pandemi dunia, tentu saja batasi ruang gerak untuk akivitas sosial diluar rumah (Kemendikbud, 2020). Pemerintah mendorong anak untuk belajar dirumah dan orang tua mengawasi, matei pendidikan dan pengajaran dikenalkan oleh pendik melalui telepon genggam menggunakan internet. Karena itu belajar dirumah berarti mempelajari apa yang harus dilaukan dirumah, belajar dirumah diambil penuh oeh orang tua untuk membimbing anak. Pemerintah Indonsia telah mengadopsi kebijakan pendidikan untuk anak belajar dirumah agar membantu mencegah penyebaran COVID-19.

Penelahaan dirumah dapat dilakukan di bawah bimbingan orang tua, bahkan rumah anak harus mendapatkan pendidikan yang positif dan produktif. Dengan perkembangan digitalisasi kompleks, pembelajran dirumah dapat dilakukan secara daring tanpa harus menghadapi pendidik serta teman-teman (Belajar \& Siswa, 2020). Jika terjadi wabah COVID-19, kemajuan eknologi bisa meningkatkan fleksibel. Optimasi pembelajaran dirumah membutuhkan aplikasi belajar serta memudahkan kegiatan belajar dirumah berjalan lebih efektif sambil mencegah COVID-19.

Pandemi COVID-19 scara khusus mengubah tatanan dunia struktur sosial negara Indonesia, salah satu perubahan yang sangat jelas yakni penyelenggaraan pendidikan menjadi "Belajar di Rumah" (Kemendikbud, 2020). Keluarga dianggap sebagai tempat belajar informal, pembelajaran informal tidak terstuktur tetapi partisipan ank bertanggung jawab untuk belajar. Belajr dirumah dimana anak berada di tengah keluarga mengambil kelas denganpendidik dari tempat berbeda yang disebut belajar jarak jauh.

Belajar dirumah selama pandemi dilakukan melalui pembelajaran jarak jauh (PPJ) dua metode digunakan, satu di website gunakan media HP atau laptopmelalui berbagai media sosial, jaringan dan aplikasi pembelajaran online (Oktaria \& Putra, 2020). Gilardini berkata bahwa online akan memberikan cara untuk belajar metode yang sesuai seperti beberapa latihan upan balik yang saling trkait, akan bekerja sama kegiatan melalui pembalajan mandiri, pembelajaran yang di personalisasi sesuai kebutuhan dan gunakan simulasi atau permainan. Semua anak akan terpengaruh kualitas yang sama, epidemi belum berakhir kemudian strategi pembelajaranonline menjadi bagian dari metode alternatif yang ditawarkan kepada anak untuk menerapkan strategi pembelajaran di era COVID-19, berurusan dengan pembelajaran online ini dharapkan menjadi solusi untuk menghindari 
anak paparan virus COVID-19. Gunakan media video untuk belajar online dan meberikanbantuan dalam bentuk video yang berisi berbagai informasi dan kegiatan bermain. Proses pemblajaran anak-anak kecil berpusat pada anak yaitu identifkasi penyelidkan, pengumpulan, komunikasi dengan mengadopsi metode ilmiah anakanak. Anak akan berperan aktif dalam prosespembelajran vido yan dikirim oleh pendidik mengunakan aplikasi pembelajaran.

Ada banyak masalah dengan pan teknologi dalam pendidikan, dan memang ada banyak hal yang perlu dipelajari. Adanya COVID-19 yang tak teduga membuat pandemi perubahan kegiatan belajar telah digantikanoleh teknologi perkembangaat saat ini (Wakhidah \& Umah, 2020). Pentingnya teknologi digital dalamkehidupan, cara berubah komunikasi dan uba cara otakbekerja dengan cepat dan pendidk saat ini dihadapkan pada berbagai platfrom da alat digitalisasi terus berubah dalam hal penyedian konten baru, pendidik melakukan transisi dari acara tatap muka tanpa pelatihan kepaltform online. Dukungan yang dapat diaksaes dan pemodelan praktifk terbaik,banyak pendidik yan masih keteteran teknologi, dan sulit untuk memantau secara langsung aspek perkembangan anak.

Pembelajaran online memang tidak mudah, terutama untuk anak usia dini dan banyak faktor yang harus dipertimbangkan sebelum menetukan platfororm. Harap diperhatikan dari latar belakang orang tua, pekerjan orang tua dan kondisi anak. Pendidik, orang tua dan anak akan berpartisipasi dalam pembelajaran online. Membutuhkan pendidik dan orang tua dapat menjalankan aplikasi yang digunakan sebagai platform untuk kegiatan belajar-mengajar.tentu saja,berbaga platform digunakan dalam kegiatan pengajaran, banyak mediajuga akn digunakan dalam pembelajaran melalui platform yang dipilih oleh pihak sekolah. Media pembelajaran sangat penting dalam proses belajar anak, pemilihan media tentunya harus disesuaikan dengan situasi, kebutuhan dan kemampuan anak didik. Perkembangan teknologi saat ini memuat para pendidik memikirkan kembali mdia pembelajaran untuk digunaka dalam pandemi ini. Penerapan keijakan pebelajaran online pada saat pandemi sudah berjalan naun belum berjalan yangditemukan mengungkapkan sepenuhnya penerapan video pembelajaran online, alasan pemilihan media video untuk salah satu metode pada anak saat pembelajaran online. Agar anak tidak merasakan rasa jenuh, menarik perhatian anak melalui video yang menyangkan dan dikenal oleh anak seperti video kartun Nussa \& Rara. Selain dapat memberikan mtode belajar pada anak yang baru, pendidik dapat memberikan pesan moral pada anak disertai dengan penjelasan pendidik kemudian orang tua untuk membimbing 
anak saat pembelajran daring dilakukan, dapat mengenalkan hal-hal yang baru pada anak sebab anak akan merasakan ketertarikan penuh jika hal yang baru dan mengasyikan.

\section{Inovasi Proses Pembelajaran Online}

Era pandemi ini proses pembelajaran adanya perubahan drastis bagi anak usia dini hingga anak kuliahan sebab yang biasanya dilakukan tatap muka kini dilakukan daring menggunakan aplikasi pembelajaran. Pembelajaran daring di Indonesia dalam pengawasan jarak jauh melaui surat ederan Kementerian Pendidikan dan Kebudayaan peraturan Nomor 4 tahun 2020 pendikan selama keadaan darura virus COVID-19 (Kemendikbud, 2020). Dalam ederan ini, kebijakan terkait masalah pemerintah pembelajaran online. Pastikan pembelajaran menjadi menyenangkan, penuh makna, membangkitkan kreativitas pada anak.

Sepanjang proses pendidikan, pembelajaran adalah yang paing akif utam. Artinya keberhasilan individu dalam mecapai tujuan pendidikan banyak hal bergantung pada bagimana belajar secara efektif. Belajar adalah dengan memberikan pendidikan dan melatih anak untuk mencapai hasil belajar. Perubahan sebagi hasil dari proses pembelajaran, berbagai bentuk seperti perbuahan dapat yakni pengetahuan, pemahman, sikap dan perilaku.

Kreativitas pendidik untuk meotivasi anak dengan mempromosikan motivasi agar berhasil mencapai tujuan pembelajaran. Desain pembelajaran yang bagus, didukung fasilitas cerdas, ditambah dengan kreativitas dan inovasi pendidik, akan meungkinkan anak lebih cenderung mencapa tujuan pembelajaran, inovasi pembelajaran sangat erat kaitanya dengan proses pembelajaran dilakukan sesua dengan tujuan yang telah ditetapkan (Belajar \& Siswa, 2020). Dimana invasi pembelajran meliputi penyusunan acara, metode atau referensi kerja dirancang untuk memberikan pengtahuan, dan pemahaman. Saat pandemi semua pihak terutama pendidikan melakukan berbagai inovasi pembelajaran, termasuk mengubah mode belajar tanpa tatap muka. Model pembelajaran lain yang dapat dilakukan oleh pendidik pembelajaran daring,metode pembelajaran daring tidak menghadirkan anak secaralangsung disebuah 1 ruangan dapat dijangkau dengan aplikasi pembelajaran.

Pembelajran daring adalah gunakan jaringan internet yan dapat diakses dan terhubung untuk belajar, flekbilitas dan kemapuan untuk memicu berbagai 
jenis ineraksi pembelajaran. Teknologi internet dan multimedia telah mampu sepenuhnya mengubah cara penyebaran pengetahuan. Ini dapat menggantikan pembelajaran menjadi daring untuk menghubungkan pendidik dengn anak untuk melakuka kegatan belajar-mengajar. Dalam implemenasinya pembelajran daring membuthkan perangkat lainnya seperti smartphone, laptop, komputer, dan tablet (Covid- \& Suhendro, 2020). Dapat diguakan untk mengakses informsvdaasi kapanpun dan dimanapun,dunia pendidikan selama WFH perlu memperkuat pembelajaran online. Berkembang nya teknologi membawa pengaruh positif dalam pendidikan termasuk tujuan pembelajaran jarak jauh berbagai media juga bisa digunakan mendukung pelaksanaan pembelajaran online.

\section{Hambatan Pembelajaran Online}

Pada awal implementasi daring anak membutuhkan secara khusus efek belajar daring, orang tua dan anak melakukan penugasan yang diberikan oleh pendidik melalui pembelajaran daring (Anugrahana, 2020). Pandemi sangat berpengaruh pada pengalaman anak sebab disutuasi pandemi anak belajar dirumah, tidak berbaur dengan teman-teman, pendidik, dan kurang nya interaksi dengan sekitar sebab adanya pandemi ini mengurangi inensitas berttemu dengan halayak.

Pembelajaran online memiliki kendala dalam praktiknya, hambatannya seperti beberapa anak tidak memiliki smartphone, keterbatasan ekonomi, koneksi internet buruk menyebakan mengirim file tugas atau foto kendala karena signal. Faktanya, data lebih lajut menunjukkan bahwa beberapa anak tidak memiliki ponsel sendiri jadi harus meminjam uang, orang tua memilki ponsel namun orang tua bekerja diluar rumah seharian. Saat menemui bebrapa kendala dalam pembelajaran daring anak mengalami bosan, pendidik perlu kreatif dalam menciptakan pembelajaran daring yang menarik untuk anak. Orang tua mengeluh karena tidak bisa mengikuti arahan dari pendidik sebab akan lebih mudah ketika pendidik menjelaskan dikarenakan orang tua tidak telaten dan tidak sabar dalam membimbing anak melakukan proses pembelajaran daring yang dilakukan dirumah.

Kendala yang dihadapi selama pandemi dimulai dari orang tua yang perlu menguasai aplikasi pembelajaran, dengan perkembangan teknologi yang pesat menguasai secara fleksibel mendorong pembelajaran (Kusuma \& Sutapa, 2021). Orang tua harus siap menghadapi tantangan zaman ini dari segi pendidikan dan keterampilan yang harus dimiliki anak untuk mengangapi perubahan. Kendala 
yang dihadapi secara internal tidak penting karena orang tua mempunya antangan baru untuk mengajar dan memahami berbagai minat anak dapat mempengaruhi pembelajaran, orang tua faktor internal keterampilan orang tua mendidk anak yang perlu berekspolarasi agar tidak ada kendala dalam belajar daring selama adanya pandemi.

Batasan orang tuajuga dapat didasarkan pada faktor eksternal yaitu pendidik, lingkungan, teman sebaya, masyarakat, sarana dan prasarana. Faktor terpenting adalah faktor eksternal media, dalam proses pembelajaran media adalah sebarkan informasi selama proses pembelajaran sehingga menjadi media belajar dirumah sangatlah penting, khususnya cocok digunakan untuk anak usia dini. Media pembelajaran menjadi sarana atau alat untuk merangsang perkembangan anak, kemudian dengan adanya orang tua menyediakan pembelajaranberbasis online. Tampaknya faktor yang mendominasi dari segi keterampilan adalah faktor internal. Kekuatan faktor ini jelas dan banyak orang tua masih belum mengerti selama pandemi untuk mendampingi anak melakukan proses pembelajaran daring, belajar dirumah selama pandemi orang tua harus bersikap mendampingi anak dengan telaten.

\section{Dampak Pandemi Perkembangan Anak}

Sebelum pandemi COVID-19 meluas di dunia dan Indonesia, sistem pembelajaran yang diterapkan bekerja sama antara sekolah dan orang tua untuk menstimulasi tumbuh kembang anak khususnya anak usia 4-6 tahun, namun, orang tua perlu memberikan perlindungan, pengasuhan, dan pendidikan kepada anak (Anugrahana, 2020). Menurut pendapa diatas dapat ditarik kesimpulan bahwa selama pandemi COVID-19 orang tua memberikan stimulasi sesuai dengan perkembangan anak, menstimulasi dan menyediakan alat permainan untuk anak untuk menunjang stimulasi agar dapat mudah diserap oleh anak sehingga pendidik di TKIT Al-Umm Cirebon bekerja sama dengan para orang tua untuk membimbing, dan mengawasi saat anak belajar online. Jika tidak ada kerja sama antara pendidik dengan orang tua tidak akan seimbang arahan dari keduanya untuk anak sebab pandemi saat ini banyak menemukan dampak pada perkembangan anak seperti anak bermain hanya di dalam rumah, sosialisasi anak berkurang sebab pemerintah menghimbau untuk semua aktivitas tidak boleh dilakukan di luar rumah pengecualian dalam hal mendesak. Maka dari itu orang tua di TKIT AlUmm Cirebon harus menciptakan suasana belajar yang menyenangkan bagi anak 
agar anak merasakan nyaman berada di rumah bersama orang tua dengan keadaan belajar di rumah yang akan membuat anak mudah bosan. Anak usia dini memiliki karaktersitik aktif dengan adanya pandemi ini membuat keaktifian anak akan menurun sehingga orang tualah yang menjadi penentu agar mampu menciptakan suasana rumah yang nyaman, dan dapat menstimulasi perkembangan anak.

Selama pandemi COVID-19 stimulasi orang tua pada anak usia 0-6 tahun meliputi berbagai bentuk stimulasi perkembangan orang tua, dilanjutkan dengan penyediaan alat bermain edukatif dan melalui media audivisiual. Stimulasi tersebut akan mendorong anak untuk mulai mengobrol sejak dini, bermain dihalaman rumah, membaca buku cerita, mewarnai bersama, dan beribadah bersama orang tua dirumah. Alat permainan ini cocok untuk anak usia dini, waktu bermain dengan anak tidak lebih dari 8 jam dalam sehari. Jika orang tua bekerja anak lebih banyak bermain dengan anggota keluarga lainnya daripada orang tua dan orang tua kehilangan melihat perkembangan anak. Orang tua merangsang perkembangan bahasa dengan menulis huruf dan angka, bercerita, dan stimulasi lainnya. Mengembangkan emosi sosial melalui memasak bersama ibu, serta mendorong perkembangan kognitif dengan menghitung jumlah bola, dan mengelompokkan mainan. Tantangan orang tua kala pandemi ini memanglah sulit selain mendimbing anak belajar daring, peran orang untuk mengasah perkembangan anak.

\section{Simpulan}

Pembelajaran anak berbasis daring mempunyai dampak dan pengaruh pada kehidupan anak, dan perkembangan anak. Dimana anak harus belajar menggunakan aplikasi belajar, anak mengalami kesulitan dalam proses pembelajaran daring seperti sulit mencerna bahan ajar pendidik yang diberikan pada anak sebab anak usia dini metode belajar yang harus dijelaskan secara langsung bukan hanya melalui penugasan, kendala dengan konsentrasi anak dikarenakan konsentrasi anak usia dini hanya bertahan 5-10 menit maka dari itu orang tua harus menciptakan suasana belajar online yang menyenangkan untuk anak. Dengan pembelajaran online dilakukan membuat interaksi anak dengan orang sekitar menjadi berubah guna mencegah penyebaran COVID-19. Selain itu, kesulitan anak dalam pembelajaran online tidak ada interaksi dengan teman sebaya disekolah, tidak bertemu dengan pendidik, memberikan dampak pada penurunan belajar anak dikarenakan orang tua yang kurang sabar dan tidak telaten dalam membimbing anak dalam belajar daring. Orang tua dalam pandemi memiliki tanggung jawab baru yakni mampu 
mendidik anak ialah peran seorang pendidik yang biasanya menajar disekolah. Orang tua bisa melapor belajar anak ke pendidk untuk mengetahui pengembangan anak, hambatan anak yang diinstruksikan dan di komunikasikan dalam proses belajar mencari solusi. Menghadapi pandemi COVID-19 juga membutuhkan orang tua memahami perjanjian kesehatan sesuai dengan seruan pemerintah. Ini harus dikomunikasikan kepada anak untuk melatih diri anak untuk menjaga diri sendiri dalam kesehatan secara maksimal sebab anak itu rentan terhadap infeksi di masa kanak-kanak.

\section{Daftar pustaka}

Aji, W., Dewi, F., Kristen, U., \& Wacana, S. (2020). DAMPAK COVID-19 TERHADAP IMPLEMENTASI PEMBELAJARAN DARING DI. 2(1), 55-61.

Anggraini, D. (2019). Metode Demonstrasi sebagai Peningkatkan Perkembangan Kognitif Anak. 1, 13-24.

Angka, M. (2021). Penggunaan Media Box of Number and Alfabeth untuk Meningkatkan Kemampuan Kognitf, Bahasa dalam. 4(1), 67-77. https://doi. org/10.31004/aulad.v4i1.93

Anhusadar, L. O. (2021). Jurnal Obsesi : Jurnal Pendidikan Anak Usia Dini Penerapan Perilaku Hidup Bersih dan Sehat Anak Usia Dini di Tengah Pandemi Covid 19 Abstrak. 5(1), 463-475. https://doi.org/10.31004/obsesi.v5i1.555

Anugrahana, A. (2020). Hambatan, Solusi dan Harapan: Pembelajaran Daring Selama Masa Pandemi COVID-19 Oleh Guru Sekolah Dasar. 282-289.

Belajar, P., \& Siswa, D. (2020). PENGALAMAN BELAJAR DARING SISWA BERKEBUTUHAN KHUSUS PADA PANDEMI COVID-19 DI SD INKLUSIF A . Pendahuluan Merabaknya pandemi corona virus disease 2019 ( COVID-19 ) menyebabkan keresahan di berbagai belahan dunia. Sebelumnya. 8, 359-376.

Covid-, M. P. (2021). Jurnal Obsesi : Jurnal Pendidikan Anak Usia Dini Analisis Dampak Work From Home pada Anak Usia Dini di. 5(1), 641-653. https:// doi.org/10.31004/obsesi.v5i1.563

Covid-, M. P., \& Suhendro, E. (2020). Strategi Pembelajaran Pendidikan Anak Usia Dini di.5(September), 133-140.

Fitri, M. (2020). Pengaruh Emergency Remote Learning Untuk Melihat Motivasi Belajar Anak Usia Dini. 2(2), 68-82. 
Inten, D. N., Permatasari, A. N., Guru, P., Anak, P., Dini, U., Bandung, U. I., Komunikasi, I., \& Bandung, U. I. (2019). Jurnal Obsesi : Jurnal Pendidikan Anak Usia Dini Literasi Kesehatan pada Anak Usia Dini melalui Kegiatan Eating Clean. 3(2), 366-376. https://doi.org/10.31004/obsesi.v3i2.188

Kemendikbud. (2020). Pedoman Pelaksanaan Belajar Dari Rumah Selama Darurat Bencana Di Indonesia Surat Edaran Sekretaris Jenderal No.15 Tahun 2020.

Khadijah. (2016). Perkembangan Kognitif Anak Usia Dini. Perdana Publishing.

Kusuma, W. S., \& Sutapa, P. (2021). Dampak Pembelajaran Daring terhadap Perilaku Sosial Emosional Anak. Jurnal Obsesi: Jurnal Pendidikan Anak Usia Dini, 5(2), 1635-1643. https://doi.org/10.31004/obsesi.v5i2.940

Masa, D. I., Pada, P., \& Usia, A. (2021). ISSN : 2580 - 4197 E ISSN : 2685-0281 ( online ). 0281.

Matematika, T., Islam, U., Imam, N., \& Padang, B. (2021). Jurnal Obsesi : Jurnal Pendidikan Anak Usia Dini Pembelajaran Matematika Anak Usia Dini di Masa Pandemi COVID-19 Tahun 2020 Abstrak. 5(1), 538-548. https://doi. org/10.31004/obsesi.v5i1.592

Mufaziah, E., \& Fauziah, P. Y. (2021). Kendala Orangtua dalam Mendidik Anak Usia Dini pada Saat Pandemi Covid 19. 5(2), 1045-1051. https://doi.org/10.31004/ obsesi.v5i2.746

Oktaria, R., \& Putra, P. (2020).PENDIDIKANANAKDALAM KELUARGA SEBAGAI STRATEGI PENDIDIKAN ANAK USIA DINI SAAT PANDEMI COVID-19 CHILD EDUCATION IN THE FAMILY AS AN EARLY CHILDHOOD. 7(1), $41-51$.

PAUD Lectura: Jurnal Pendidikan Anak Usia Dini, Vol 4, No 1, Oktober 2020. (2020). 4(1), 74-87. https://doi.org/10.31849/paud-lectura.v

Ra, D. I., \& Bima, B. (2021). Implementasi kurikulum 2013 (terpadu) di ra baiturrahman bima cirebon. 6(1), 47-58.

Satrianingrum, A. P., Prasetyo, I., Anak, P., Dini, U., \& Yogyakarta, U. N. (2021). Jurnal Obsesi: Jurnal Pendidikan Anak Usia Dini Persepsi Guru Dampak Pandemi COVID-19 terhadap Pelaksanaan Pembelajaran Daring di PAUD Abstrak. 5(1), 633-640. https://doi.org/10.31004/obsesi.v5i1.574

Suyadi \& Maulidya Ulfah. (2015). Konsep Dasar PAUD. PT Raja Grafindo Persada. 
Ulfah, M. (2020). Jurnal Obsesi: Jurnal Pendidikan Anak Usia Dini Pendekatan Holistik Integratif Berbasis Penguatan Keluarga pada Pendidikan Anak Usia Dini Full Day Abstrak. 4(1), 10-19. https://doi.org/10.31004/obsesi.v4i1.255

Wakhidah, E. W., \& Umah, F. M. (2020). PENERAPAN VIDEO PEMBELAJARAN DARING ANAK USIA DINI PADA MASA PANDEMI COVID-19 pertama kali di Indonesia .( COVID-19, n . d.) Dengan adanya Virus ini pemerintah ( COVID-19). Pembatasan aktivitas adalah salah satu kebijakan daripemerintah harus dijalani. 3(2), 140-160. 
